\title{
Assessment of Nutritional Composition and Antifungal Potential of Bacteriocinogenic Lactic Acid Bacteria from "Kati" against Toxigenic Aspergillus flavus
}

\author{
Paul Oladimeji Gabriel ${ }^{1}$, Clement Olusola Ogidi ${ }^{2}$, Oladipo Oladiti Olaniyi ${ }^{1}$, \\ Bamidele Juliet Akinyele ${ }^{1}$ \\ ${ }^{1}$ Department of Microbiology, The Federal University of Technology, PMB 704 Akure, Nigeria \\ ${ }^{2}$ Biotechnology Unit, Biological Sciences, Kings University, PMB 555, Odeomu, Nigeria
}

SUMMARY

In this study, the nutrient contents of "Kati", a fermented cereal-based food, was revealed and antifungal activity of bacteriocin producing lactic acid bacteria (LAB) from "Kati" was assessed against aflatoxigenic Aspergillus flavus (A. flavus). The protein content $(9.29 \%)$ of "Kati" was higher than ( $<<0.05)$ wet milled-fermented sorghum (6.17\%). During fermentation of milled sorghum to ready-to-eat 'Kati', anti-nutrient contents was reduced $(\mathrm{p}<0.05)$ from 1.22 to $0.72 \mathrm{mg} / 100 \mathrm{~g}, 3.13$ to $1.13 \mathrm{mg} / 100 \mathrm{~g}$ and 7.31 to $3.02 \mathrm{mg} / 100 \mathrm{~g}$ for tannin, phenol and phytates, respectively. Molecular technique revealed the identity of isolated LAB as Lactobacillus pentosus BS MP-10, L. paracasei 4G330, L. brevis ABRIINW, L. casei KG-5, $L$. sakei strain RFI LAB03, L. fermentum JCM 8607, L. plantarum KLDS 1.0607, L. rhamnosus JCM 8602 and $L$. lactis XLL1734. Among the isolated LAB, L. plantarum, L. lactis and L. fermentum have significant $(\mathrm{p}<0.05)$ zones of inhibition of $11.0 \mathrm{~mm}, 9.1 \mathrm{~mm}$ and $7.8 \mathrm{~mm}$, respectively, against aflatoxigenic $A$. flavus. The pronounced antifungal potency of $L$. plantarum cell free supernatant could be attributed to the presence of 3-phenyllactic acid, benzeneacetic acid, plantaricin (bacteriocin) as revealed by gas chromatography/mass Spectrometry (GC-MS). LAB produced metabolites with antifungal property that contributed to shelf life, flavor and nutrient contents of fermented foods.

Key words: cereal, proximate, 3-phenyllactic acid, benzeneacetic acid, GC-MS, fermentation

Corresponding author:

Clement Olusola Ogidi

e-mail: clementogidi@yahoo.com 


\section{INTRODUCTION}

"Kati", which is also called "Egidi" is a customary cereal-based and ready-to-eat food that is indigenous to Akoko town in Ondo State, southwestern Nigeria. "Kati" is traditionally prepared from fermented and cooked sorghum or millet slurry, wrapped in Ficus carica and Thaumatococcus daniellii leaves. It is usually consumed as snacks in hot afternoon by breaking it into cold water (1). A wide range of cereal-based fermented foods and their related products from different countries alleviate food insecurity in different contexts (2): "Dosa" and "Idli" are popular traditional cereal fermented foods in South India and many parts of Sri Lanka (3). "Injera" is an undisputed national food of Ethiopians and it is made from different cereals, including finger millet, sorghum, teff, corn, and barley (3). "Soy sauce" is a blend of soya beans and coarse wheat into fermented dark brown liquid, commonly consumed in Japan and China (4). "Yosa" is an indigenous food consumed in Finland, produces from oat bran pudding that has been cooked in water and fermented with LAB and Bifidobacteria sp. (5). "Tarhana" is a Turkish fermented food from wheat, which is rich in protein and vitamins with an acidic and sour taste, having a strong yeasty flavour (5). "Pito" is a cereal-based fermented food prepared from sorghum, millet and maize with varying alcohol content, which is often consumed in Ghana and Southern Nigeria (6). "Ogi", a popular fermented food from West Africa, is made by lactic acid fermentation of corn, but sometimes, sorghum or millet and soybeans may be added to improve its nutritive value (5). "Masa" is also a Nigeria traditional fermented food product made from maize (3).

Fermentation of cereals into based-foods is a popular custom in Africa that improves the availability of foods (7). With this regard, general awareness of the importance of fermented foods has not only been based on benefits of fermented foods, provision of energy, body maintenance but health benefits of fermenting microorganisms. Some microorganisms involved in fermentation, especially LAB and yeast, are known to produce flavour enhancing compounds, important enzymes, amino acids and antimicrobial substances such as bacteriocin, organic acids, hydrogen peroxide, antifungal peptides and other compounds that contribute to extensive shelf life of food products (8). Fermented food products from cereals are nutritious, with some antifungal
LAB (9). In the findings of Afolabi et al. (10), Lactobacillus casei, Lactobacillus salivarius, Lactobacillus jensenii, Lactobacillus cellobiosus, Lactobacillus plantarum, Lactobacillus delbrueckii, and Lactobacillus fermentum were predominantly isolated from traditionally fermented "Kati" and their presence was attributed to organoleptic property of "Kati". However, there is little or no report on the occurrence of antifungal LAB (bacteriocin producer) from "Kati". Hence, this research aimed to evaluate the nutrient contents and to assess antifungal activity of bacteriocin producing LAB from "Kati" against aflatoxigenic fungus.

\section{MATERIALS AND METHODS}

\section{Source of grains}

Sorghum (Sorghum bicolor) was purchased from a local retail outlet at King's market, Akure. It was transported in a clean bag to Microbiology laboratory, The Federal University of Technology, Akure (FUTA), Nigeria for further analysis.

\section{Source of toxigenic A. flavus}

The studied toxigenic A. flavus was isolated from damp infested sorghum. Grains were finely grinded with a mill machine (5657 HAAN 1 TYPE ZM1, Retsch GmbH, Haan, Germany). One gram of milled sorghum was dissolved in $9 \mathrm{ml}$ sterile distilled water, serially diluted and aliquots were aseptically dispensed on Potato Dextrose Agar (PDA) plates using spread plate method. PDA plates were incubated for 7 days at $25 \pm 2{ }^{\circ} \mathrm{C}$. Colonies of $A$. flavus were screened and identified based on morphology and mycelia character. The identification of mould was determined by comparing the observed morphological characteristics with those described by Samson et al. (11).

\section{Preparation of "Kati"}

The traditionally fermented gruel was processed according to the method of local producers in Arigidi Akoko with little modification that majorly focused on improving hygiene (Figure 1). Briefly, $500 \mathrm{~g}$ of sorghum was sorted and washed with clean water and steeped in $1,000 \mathrm{ml}$ of water at $28 \pm 2^{\circ} \mathrm{C}$ for $48 \mathrm{~h}$. Thereafter, water was removed and grains were wet milled. The slurry was allowed to ferment for $24 \mathrm{~h}$, after which it was placed in a vessel, pre- 


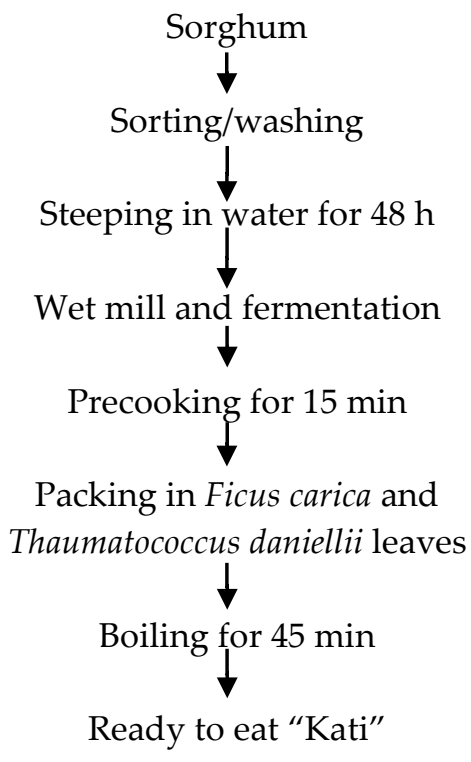

Figure 1. Processes involved during the production of 'Kati'

A

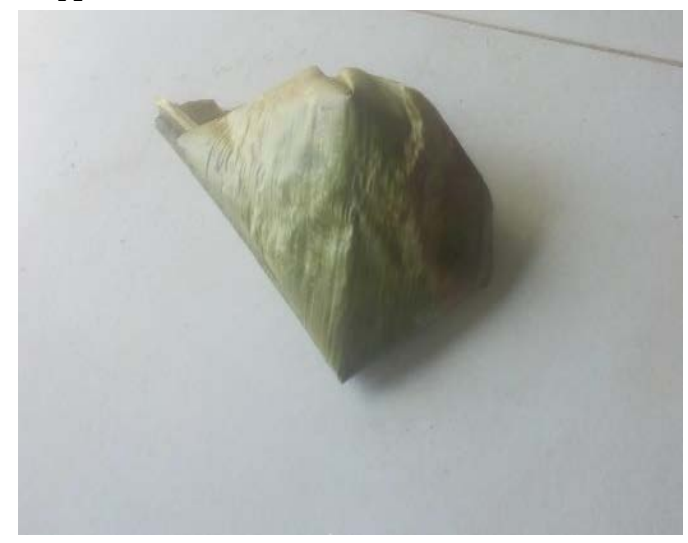

$B$

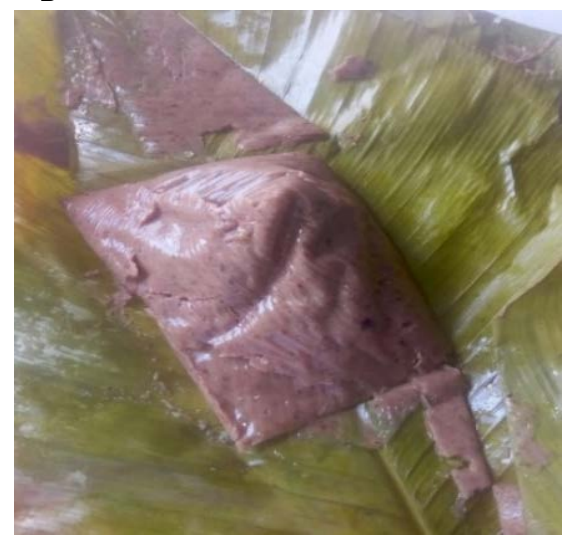

Figure 2. A sample of (a) "Kati"wrapped in F. carica and T. daniellii leaves (b) unwrapped "Kati"

cooked for 15 min and thoroughly mixed with continuous stirring using a wooden turning stick to obtain a thick paste. The pre-cooked "Kati" was moulded by wrapping in Ficus carica and Thaumatococcus daniellii leaves (Figure 2). The wrapped "Kati" was cooked in a pot under smoldering fire for $45 \mathrm{~min}$, then offloaded and allowed to cool, after which was ready for consumption. Samples were aseptically taken at each stage of production for further analysis.

\section{Isolation of LAB from "Kati"}

LAB were isolated from "Kati" by weighing 10 $\mathrm{g}$ into $90 \mathrm{ml}$ of bacteriological peptone water (Oxoid,
Basingstoke, UK). After homogenization, a tenfold serial dilution of sample was carried out and $0.1 \mathrm{ml}$ of dilutions (10 - 5) was plated onto de Man, Rogosa and Sharpe (MRS) agar (Oxoid, Basingstoke, UK). The MRS plates were incubated at $37^{\circ} \mathrm{C}$ under anaerobic condition for $48-72 \mathrm{~h}$. Pure colonies were isolated by sub-cultured, stored on MRS slants and maintained at $4^{\circ} \mathrm{C}$ for further studies. Gram's staining, spore staining, and biochemical tests such as catalase, nitrate reduction, oxidase, urease production, and sugar fermentation were carried out according to the methods described by Cheesbrough (12). Staining reactions and interpretation of biochemical tests were used for the identification of LAB according to Cowan and Steel (13). 


\section{Identification of $\mathrm{LAB}$ isolates using $16 \mathrm{~S}$ rRNA gene amplification}

LAB isolates were grown overnight in a liquid MRS broth at $37^{\circ} \mathrm{C}$ and transferred to Eppendorf tube. The samples were spun at 14,000 rpm for $2 \mathrm{~min}$ after which the supernatant was discarded and DNA was extracted using cetyl trimethylammonium bromide (14). Afterwards, DNA was re-suspended in $100 \mu \mathrm{l}$ of sterile distilled water. DNA concentration of samples was measured on spectrophotometer at $260 \mathrm{~nm}$ and the genomic purity was also determined. Agarose gel (1.0\%) was used to check DNA and visualized using UV light. The primer used for PCR amplification was 16S universal primer for bacteria; the sequence for the forward primer was 5'AGAGTTTGATCCTGGCTCAG3' and reverse primer was 5'ACGGCTACCTTGTTACGACTT3'. PCR mix was made up of $1 \mu \mathrm{l}$ of $10 \mathrm{X}$ buffer, $0.4 \mu \mathrm{l}$ of $50 \mathrm{mM} \mathrm{MgCl}$, $0.5 \mu \mathrm{l}$ of 2.5 mMdNTPs, $0.5 \mu 15 \mathrm{mM}$ forward primer, $0.5 \mu \mathrm{l}$ of $5 \mathrm{mM}$ reverse primer, 0.05 $\mu l$ of 5 units/ul Taq with $2 \mu$ l of template DNA and $5.05 \mu \mathrm{l}$ of distilled water. The PCR profile used has an initial denaturation temperature of $94^{\circ} \mathrm{C}$ for 3 mins, followed by 30 cycles of $94^{\circ} \mathrm{C}$ for $60 \mathrm{~s}, 56^{\circ} \mathrm{C}$ for $60 \mathrm{~s}, 72^{\circ} \mathrm{C}$ for $120 \mathrm{~s}$ and the final extension temperature of $72^{\circ} \mathrm{C}$ for $5 \mathrm{~min}$ and the $10^{\circ} \mathrm{C}$ hold for 1 hour. Afterwards, the amplicon was purified before sequencing with $2 \mathrm{M}$ sodium acetate (15).

\section{Determination of nutrient and anti-nutrient contents in "Kati"}

The proximate, mineral and anti-nutrient compositions of sorghum, wet milled and fermented sorghum, and the finished "Kati" were determined according to the methods described by Association of Official Analytical Chemists (16). Total carbohydrates content of the samples was calculated by subtracting the percent of moisture, crude protein, crude fibre, crude fat, and ash from 100.

\section{Screening of $A$. flavus for aflatoxin B1}

A test for aflatoxin was carried out according to the method described by Okwu et al. (17). The reverse side of toxigenic $A$. flavus plates were exposed to UV light at $360 \mathrm{~nm}$, and bright greenish-yellow fluorescence indicated the presence of aflatoxin. Aflatoxin analysis was further carried out with thin layer chromatography (TLC) according to Criseo et al. (18) with slight modifications. A. flavus in broth (5 $\mathrm{ml}$ ) was transferred into a $250 \mathrm{ml}$ conical flask; $15 \mathrm{ml}$ of distill water and $50 \mathrm{ml}$ of chloroform were added and shaken for $1 \mathrm{~h}$. The sample was filtered in a separating funnel, while chloroform layer was allowed to filter through anhydrous sodium-sulphate. The extraction was repeated twice using $50 \mathrm{ml}$ chloroform and the collected filtrate was concentrated. The filtrate of each sample was re-dissolved in $1 \mathrm{ml}$ chloroform and $10 \mu \mathrm{l}$ of the re-dissolved filtrates were applied on TLC plates. The plates were developed in a solvent system of toluene: ethyl acetate: formic acid (6:3:1 v:v:v) in a chromatographic tank for about $25 \mathrm{~min}$. Pure aflatoxin (0.0025 $\mu \mathrm{g}$ ) used as standard was spotted on TLC plates in parallel lane and visualized under the UV light (366 $\mathrm{nm})$.

\section{Screening of LAB for bacteriocin production}

Bacteriocin-producing LAB were screened using the method described by Salasiah et al. (19). Briefly, LAB isolated from "Kati" were grown in MRS broth, incubated at $37^{\circ} \mathrm{C}$ for $48 \mathrm{~h}$ and their cell free supernatant (CFS) was obtained. Thereafter, CFS was centrifuged at $6000 \mathrm{rpm}$ for $10 \mathrm{~min}$ and sediment was separated from supernatant by decantation. To rule out the inhibitory effect of other LAB metabolites, apart from bacteriocin, supernatant was filtered $(0.22 \mu \mathrm{m})$ and $35 \mu$ l of CFS aliquot was added to the first well on a prepared solidified MRS agar plate. The remaining CFS was adjusted to $\mathrm{pH}$ 6.0 with $1 \mathrm{~mol} \mathrm{NaOH}$ in order to prevent a likely inhibition due to organic acids. CFS (35 $\mu \mathrm{l})$ was transferred to the second well. The remaining neutralized CFS was then treated with $1.0 \mathrm{mg} / \mathrm{ml}$ of catalase (Sigma, USA) at $25^{\circ} \mathrm{C}$ for $30 \mathrm{~min}$ to exclude the possible inhibitory action of $\mathrm{H}_{2} \mathrm{O}_{2}$. This was filtered and transferred into the third well on the agar plate.

\section{Gas chromatography/mass spectrometry (GC-MS) analyses of L. plantarum CFS}

GC-MS analysis of L. plantarium CFS as the most effective and bacteriocin producing $\mathrm{LAB}$ was qualitatively performed using Varian 4000 GC-MS system (Agilent Technologies, Santa Clara, CA, USA) to show the component of bacteriocin. The ionization voltage was maintained at $70 \mathrm{eV}$. The injection port temperature was ensured as $250^{\circ} \mathrm{C}$ and nitrogen flow rate was $1.0 \mathrm{ml} / \mathrm{min}$. The sample $(2 \mu \mathrm{l})$ was injected in split mode as 10:1 into the GC-MS 
equipment. The compounds were separated on a 30 $\mathrm{m}$ long capillary column (HP-5MS), which is 0.25 $\mathrm{mm}$ in diameter and with $0.25 \mu \mathrm{m}$ thick stationary phase layer (5\% phenyl)-methylpolysiloxane. The instrument was set to an initial temperature of $110^{\circ} \mathrm{C}$ for $2 \mathrm{~min}$. At the end of this period, the oven temperature was increased to $280^{\circ} \mathrm{C}$ at an increased rate of $6^{\circ} \mathrm{C}$ per min and the oven was maintained at this temperature for $9 \mathrm{~min}$. The total analysis time was 55 min and the mass spectral scan was set within 50 $650 \mathrm{~m} / \mathrm{z}$. Identification of chemical structure of secondary metabolites was based upon the interpretation of mass spectra libraries of NIST/EPA/NIH.

In vitro antifungal activity of LAB against toxigenic A. flavus

Antifungal LAB isolated from "Kati" were tested against toxigenic A. flavus using agar overlay method described by Lind et al. (20) with slight modifications. Briefly, LAB was cultured in sterile MRS broth and incubated at $35 \pm 2^{\circ} \mathrm{C}$ for $48 \mathrm{~h}$ under the anaerobic condition. After incubation, crude culture of each $\mathrm{LAB}$ was centrifuged to obtain a CFS. An aliquot of $100 \mu \mathrm{l}$ from CFS of LAB were aseptically transferred into a separate well of $6.0 \mathrm{~mm}$ containing $10 \mathrm{ml}$ of MRS agar. Sterile distilled water $(100 \mu \mathrm{l})$ was used as a negative control, while an an- tifungal drug ketoconazole was used as a positive control. The inoculated plates were incubated at 35 ${ }^{\circ} \mathrm{C}$ and observed for growth for 2 days. After incubation, plates were then overlaid with $10 \mathrm{ml}$ of PDA, inoculated with $100 \mu \mathrm{l}$ of mould spore ( $10^{6}$ spores/ $\mathrm{ml}$ ) and incubated at $28 \pm 2^{\circ} \mathrm{C}$ for $72 \mathrm{~h}$. Thereafter, zones of inhibition were recorded in millimeter $(\mathrm{mm})$. The synergistic effect of the best three CFS of $\mathrm{LAB}$ was further tested against toxigenic $A$. flavus.

\section{Statistical analysis}

All experimental studies were performed in replicate $(n=3)$. Data were subjected to one-way analysis of variance (ANOVA) and values were presented as mean \pm standard deviation (SD). Tests of significant differences were determined by Duncan's Multiple Range Test at $p<0.05$. The statistical analysis was carried out using Statistical Package for Social Sciences (SPSS) version 23 software undertaken.

\section{RESULTS}

Proximate, mineral and anti-nutritive contents of 'Kati'

Table 1 shows nutritive and anti-nutritive composition of "Kati" at the various stages of pro-

Table 1. Proximate (\%), mineral $(\mathrm{mg} / 100 \mathrm{~g})$ and anti-nutrient $(\mathrm{mg} / 100 \mathrm{~g})$ contents of fermented sorghum and finished 'Kati'

\begin{tabular}{|c|c|c|c|}
\hline Test & Sorghum & $\begin{array}{l}\text { Wet milled and } \\
\text { fermented sorghum }\end{array}$ & \begin{tabular}{|l} 
Finished \\
"Kati"
\end{tabular} \\
\hline \multicolumn{4}{|c|}{ Proximate (\%) } \\
\hline Moisture & $44.81 \pm 0.47^{\mathrm{a}}$ & $63.70 \pm 0.69^{a}$ & $62.46 \pm 1.44^{\mathrm{a}}$ \\
\hline Protein & $4.47 \pm 0.75^{\mathrm{c}}$ & $6.17 \pm 0.49^{b}$ & $9.29 \pm 0.21^{\mathrm{a}}$ \\
\hline Fat & $5.09 \pm 1.11^{\mathrm{a}}$ & $3.03 \pm 0.28^{\mathrm{b}}$ & $3.04 \pm 0.10^{\mathrm{b}}$ \\
\hline Fiber & $6.55 \pm 0.58^{\mathrm{a}}$ & $1.89 \pm 0.24^{\mathrm{b}}$ & $2.03 \pm 0.00^{\mathrm{b}}$ \\
\hline Ash & $2.18 \pm 0.69^{a}$ & $2.22 \pm 0.75^{\mathrm{a}}$ & $1.19 \pm 0.08^{\mathrm{b}}$ \\
\hline $\mathrm{CHO}$ & $36.90 \pm 1.33^{\mathrm{a}}$ & $22.99 \pm 0.87^{\mathrm{b}}$ & $22.00 \pm 0.98^{\mathrm{b}}$ \\
\hline \multicolumn{4}{|c|}{ Minerals (mg/100 g) } \\
\hline $\mathbf{K}$ & $7.63 \pm 0.03^{a}$ & $1.27 \pm 0.03^{b}$ & $1.14 \pm 0.02^{\mathrm{b}}$ \\
\hline $\mathrm{Ca}$ & $14.30 \pm 0.03^{a}$ & $5.43 \pm 0.03^{c}$ & $11.30 \pm 0.03^{\mathrm{b}}$ \\
\hline $\mathrm{Na}$ & $5.02 \pm 0.03^{a}$ & $4.15 \pm 0.04^{\mathrm{b}}$ & $5.43 \pm 0.03^{a}$ \\
\hline $\mathrm{Mg}$ & $4.27 \pm 0.03^{\mathrm{b}}$ & $4.40 \pm 0.03^{\mathrm{b}}$ & $7.43 \pm 0.03^{a}$ \\
\hline \multicolumn{4}{|c|}{ Anti-nutrients (mg/100 g) } \\
\hline Tannin & $1.22 \pm 0.03^{\mathrm{a}}$ & $0.75 \pm 0.04^{b}$ & $0.72 \pm 0.04^{\mathrm{b}}$ \\
\hline Phytates & $7.31 \pm 0.02^{\mathrm{a}}$ & $3.16 \pm 0.04^{b}$ & $3.02 \pm 0.02^{c}$ \\
\hline Phenol & $3.13 \pm 0.02^{\mathrm{a}}$ & $2.23 \pm 0.04^{b}$ & $1.13 \pm 0.02^{c}$ \\
\hline
\end{tabular}


Values are mean of replicates $(n=3)$. Values with different alphabet along the rows are significantly different from each other at $\mathrm{p}<0.05$

duction. There was an increase in moisture and protein contents of fermented gruel from 44.81 to $62.46 \%$ and 4.47 to $9.29 \%$, respectively, when compared to unfermented sorghum. There was a decrease $(p<0.05)$ in ash, crude fibre, fat and carbohydrate contents in sorghum to finished "Kati" from 2.18 to $1.19 \%, 6.55$ to $2.03 \%, 5.09$ to $3.04 \%$ and 36.90 to $24.03 \%$, respectively. Potassium, calcium and sodium in unfermented sorghum respectively reduced from $7.63 \mathrm{mg} / 100 \mathrm{~g}, 14.3 \mathrm{mg} / 100 \mathrm{~g}$ and $5.02 \mathrm{mg} / 100 \mathrm{~g}$ to $1.27 \mathrm{mg} / 100 \mathrm{~g}, 5.43 \mathrm{mg} / 100 \mathrm{~g}$ and $5.51 \mathrm{mg} / 100 \mathrm{~g}$ in wet milled and fermented sorghum. The finished "Kati" had potassium and calcium contents of 1.14 $\mathrm{mg} / 100 \mathrm{~g}$ and $11.3 \mathrm{mg} / 100 \mathrm{~g}$, respectively. An increase $(\mathrm{p}<0.05)$ in sodium content $(5.43 \mathrm{mg} / 100 \mathrm{~g})$ was observed, which could be due to deliberate addition of table salt $(\mathrm{NaCl})$ to the finished product. The anti-nutrient contents - tannin, phytate and phenol decreased $(p<0.05)$ from $1.22 \mathrm{mg} / 100 \mathrm{~g}, 7.31 \mathrm{mg} /$ $100 \mathrm{~g}$ and $3.13 \mathrm{mg} / 100 \mathrm{~g}$ in sorghum to $0.75 \mathrm{mg} / 100$ $\mathrm{g}$, $3.16 \mathrm{mg} / 100 \mathrm{~g}$ and $2.23 \mathrm{mg} / 100 \mathrm{~g}$, respectively after fermentation of wet milled sorghum. The lowest anti-nutritional contents of tannin $(0.72 \mathrm{mg} / 100 \mathrm{~g})$, phytate $(3.02 \mathrm{mg} / 100 \mathrm{~g})$ and phenol $(1.13 \mathrm{mg} / 100 \mathrm{~g})$ were observed in the finished "Kati".

\section{Molecular identification of bacterial isolates}

Molecular identities of the LAB isolates are shown in Table 2. The lengths of amplified products were 1676, 1475, 1740, 1508, 1453, 1515, 1471, 1511 and 1449 base pair for L. pentosus, L. paracasei, L. brevis, L. casei, L. sakei, L. fermentum, L. plantarum, $L$. rhamnosus and L. lactis respectively (Figure 3). Based on the 16SrRNA sequences, L. pentosus, L. plantarum, L. brevis, L. fermentum, L. sakei, L. casei, L. paracasei, $L$. rhamnosus and L. lactis were confirmed to be $L$. pentosus BS MP-10, L. paracasei 4G330, L. brevis ABRIINW, L. casei KG-5, L. sakei RFI LAB03, L. fermentum JCM 8607, L. plantarum KLDS 1.0607, L. rhamnosus JCM 8602 and L. lactis XLL1734, respectively.

Antifungal activity of bacteriocin producing LAB against aflatoxigenic $A$. flavus

The zones of inhibition displayed by CFS of $L$. plantarum, L. fermentum, and L. lactis as well as their synergistic combination against toxigenic A. flavus were presented in Table 3. L. plantarum have the highest zone of inhibition against toxigenic $A$. flavus with $11.0 \mathrm{~mm}$, followed by L. lactis and L. fermentum with inhibitory zones of $9.1 \mathrm{~mm}$ and $7.8 \mathrm{~mm}$, respectively. The major antifungal components detected in the CFS of L. plantarum isolated from "Kati" using GCMS include: plantaricin, benzeneacetic acid and 3-phenyllactic acid with their empirical formula and molecular weight (Figure 4).

Table 2. Molecular identity of LAB isolated from "Kati"

\begin{tabular}{l|l|l|c}
\hline \hline${ }^{*}$ Microorganisms & Molecular identity & Genbank accession no. & Similarity (\%) \\
\hline Lactobacillus pentosus & L. pentosus strain BS MP-10 & FR871789.1 & 99 \\
\hline${ }^{*}$ Lactobacillus plantarum & L. paracasei strain 4G330 & MK026811.1 & 96 \\
\hline Lactobacillus brevis & L. brevis strain ABRIINW & JN368471.1 & 99 \\
\hline${ }^{*}$ Lactobacillus fermentum & L. casei strain KG-5 & KF263160.1 & 92 \\
\hline Lactobacillus sakei & L. sakei strain RFI LAB03 & EU141957.1 & 91 \\
\hline${ }^{\sharp}$ Lactobacillus casei & L. fermentum strain JCM 8607 & AB690195.1 & 96 \\
\hline${ }^{\sharp}$ Lactobacillus paracasei & L. plantarum strain KLDS 1.0607 & EU419597.1 & 98 \\
\hline Lactobacillus rhamnosus & L. rhamnosus strain JCM 8602 & AB690191.1 & 98 \\
\hline Lactococcus lactis & L. lactis strain XLL1734 & MG983982.1 & 89 \\
\hline \hline
\end{tabular}

*LAB isolated from "Kati"

\#Isolated Lactobacillus spp. has more closeness to another LAB strain after using molecular tool 


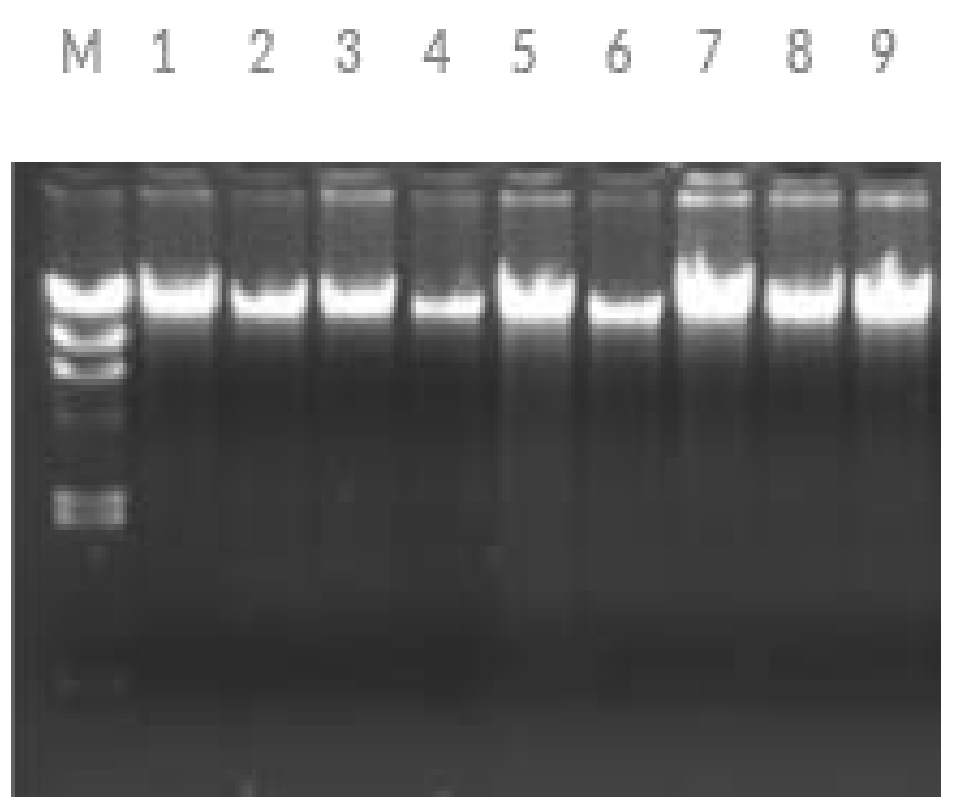

Figure 3. Agarose gel electrophoresis plate of $L A B$ isolates

Keys: M = Molecular marker, 1 = Lactobacillus pentosus (1676); 2 = Lactobacillus plantarum (1471); 3 = Lactobacillus brevis (1740); 4 = Lactobacillus fermentum (1515); 5 = Lactobacillus sakei (1453), 6 = Lactobacillus casei (1508), 7 = Lactobacillus paracasei (1475), 8 = Lactobacillus rhamnosus (1511) and 9

= Lactococcus lactis (1449).

Table 3. Zones of inhibition ( $\mathrm{mm}$ ) of $L A B$ cell free supernatant and their synergistic effects against toxigenic A. flavus

\begin{tabular}{l|l}
\hline \hline LAB isolates & Zones of inhibition \\
\hline L. plantarum & $11.00 \pm 0.43^{\mathrm{b}}$ \\
\hline L. lactis & $9.10 \pm 0.16^{\mathrm{c}}$ \\
\hline L. fermentum & $7.80 \pm 0.41^{\mathrm{d}}$ \\
\hline L. rhamnosus & $4.00 \pm 0.00^{\mathrm{e}}$ \\
\hline L. paracasei & $3.90 \pm 0.00^{\mathrm{f}}$ \\
\hline L. pentosus & $3.80 \pm 0.01^{\mathrm{f}}$ \\
\hline L. casei & $3.30 \pm 0.02^{\mathrm{g}}$ \\
\hline L. brevis & $3.20 \pm 0.02^{\mathrm{g}}$ \\
\hline L. sakei & $3.00 \pm 0.01 \mathrm{~g}$ \\
\hline Synergistic effect & \\
\hline L. plantarum+ L. lactis & $6.30 \pm 0.04^{\mathrm{d}}$ \\
\hline L. fermentum+ L. lactis & $5.10 \pm 0.05^{\mathrm{e}}$ \\
\hline L. plantarum+ L. fermentum & $4.20 \pm 0.10^{\mathrm{e}}$ \\
\hline L plantarum+ L. fermentum+ L. lactis & $7.40 \pm 0.20^{\mathrm{d}}$ \\
\hline Ketoconazole & $16.10 \pm 1.20^{\mathrm{a}}$ \\
\hline \hline
\end{tabular}

Values are mean of replicates $(n=3)$. Value with different alphabet along column are significantly different from each other at $\mathrm{p}<0.05$ 


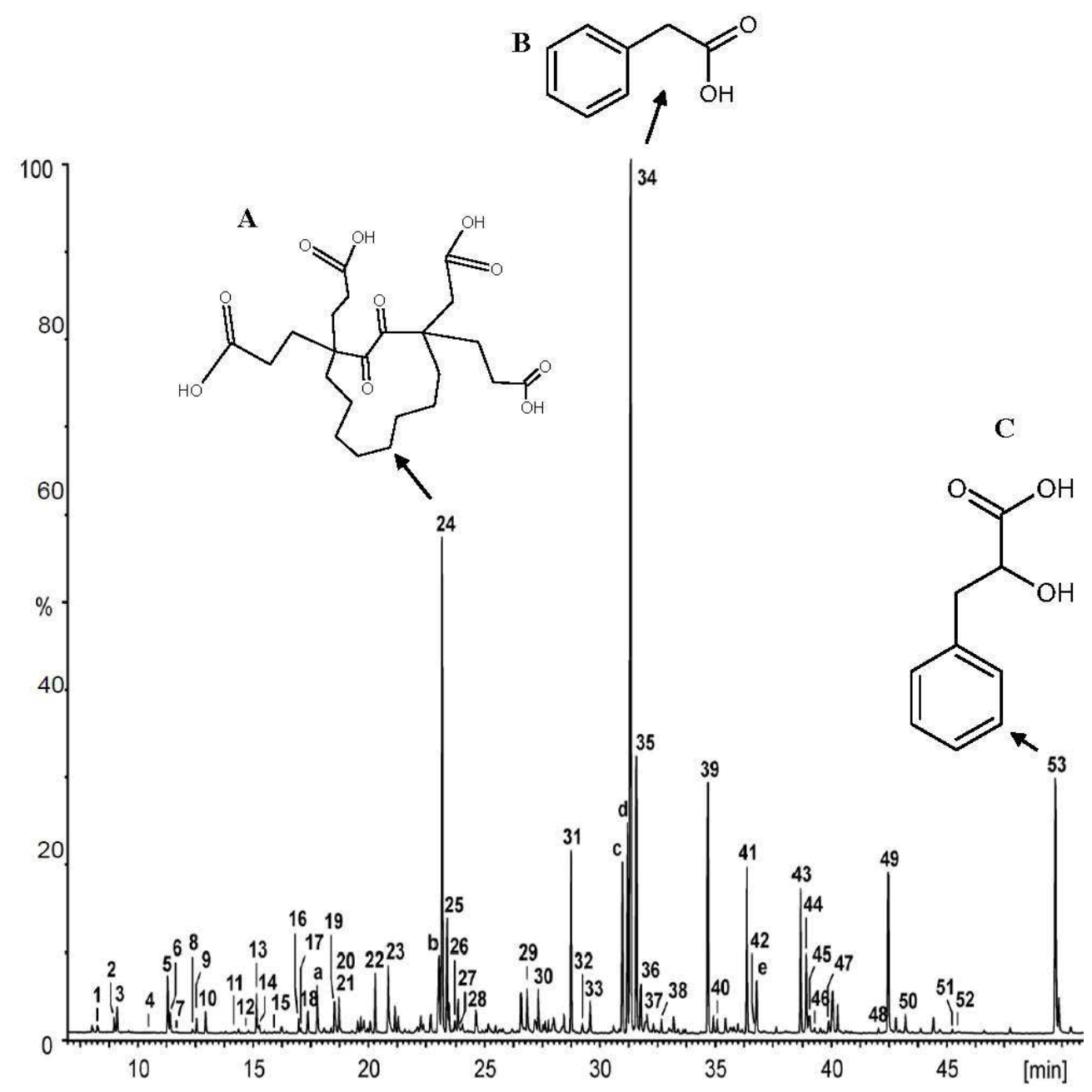

Figure 4: Chromatogram with peak

A: plantaricin C24H36O10 (484.542 g/mol), B: benzeneacetic, C9H10BrNO2 (244.08 g/mol) and

C: 3-phenyllactic C9H10O3 $(166.17 \mathrm{~g} / \mathrm{mol})$ from CFS of L. plantarum

\section{DISCUSSION}

The appreciable features of "Kati" could be attributed to its nutritional quality as well as aroma from leaves used for wrapping. Studies have shown that the presence of aromatic (sweet smelling) oil in $T$. danielli leaf enhance flavour in foods $(21,22)$. The methanol extract of $F$. carica leaf has been reported to possess a strong antibacterial activity against oral bacteria (23). F. carica leaf could impact natural antibacterial enhancement to the food. These are medicinal leaves commonly used to treat various illnesses such as gastrointestinal (colic, indigestion, loss of appetite, and diarrhea), respiratory (sore throats, coughs, and bronchial problems), cardiovascular disorders, inflammation and act as antispasmodic remedy (24).
Fermentation reduced the anti-nutritional content of "Kati". The reduction could be linked to solubility of tannins in water during fermentation (25). Also, some microorganisms produce enzymes that break down anti-nutrient. Phytase produced by L. brevis and Bacillus subtilis breakdown phytates in fermented foods (26). A similar observation was reported by Esekheigbe and Onimawo (27) when fermentation resulted in significant reduction of antinutrients during the fermentation of African walnut. There was an increase in protein content of "Kati". This could be as a fact that fermentation aids in liberation of nutrients locked (indigestible materials) in plant structures and anabolic synthesis of several complex growth factors by microorganisms (28). However, fermentation reduced fat and carbohydrate contents of "Kati". This could be a result of 
microorganisms utilizing carbohydrate and fat as a source of energy (25). A similar observation was reported by Modupe et al. (29). The researchers reported that microorganisms produce amylase, glucosidase and galactanase to degrade carbohydrates into simple sugars and thus utilize the sugar as energy source, which is also used for other metabolic activities. Fermentation significantly increased all minerals determined in wet milled sorghum except for potassium, which could possibly be due to leaching. A similar observation was reported by Esekheigbe and Onimawo (27). The researchers reported an increase in mineral contents as a result of fermentation and heat treatment on the nutritional composition of African walnut.

The presence of LAB in "Kati", particularly $L$. plantarum, L. lactis, L. casei, L. fermentum and L. brevis agrees with findings of Suman et al. (3). Researchers isolated and identified similar bacteria from cerealbased fermented foods/beverages; "Idli", "Dosa", "Injera", "Soy sauce", "Yosa", "Ogi" and "Masa" around the world. Hence, in fermented foods, the presence of LAB and their products improve dietary status and shelf life with various health benefits (2). The importance of LAB has been principally linked to improvement of gastrointestinal health, lactose intolerance, ulcer, cancer and immunosuppresion at intestinal and systemic level (30). 16S rRNA gene sequence revealed the identity of nine LAB isolated from "Kati". The genus Lactobacillus was predominant, representing $89 \%$ of isolates, whereas Lactococcus lactis strain XLL1734 represented the remaining $11 \%$. LAB are frequently isolated from locally fermented foods and improve their shelf life due to inhibitory substances. LAB possess a strainspecific spectrum and inhibitory mechanism against different moulds and yeast $(31,32)$.

The use of CFS from isolated LAB against toxigenic $A$. flavus reflect a remarkable inhibitory potential as an alternative source of antifungal agent. Russo et al. (33) stated that incorporation of CFS into agar plates as antifungal agent was a fast method to establish anti-mycotic potential of LAB. Hence, an in vitro study revealed a noteworthy inhibition of toxigenic $A$. flavus by isolated LAB from "Kati". The findings of Ghazvini et al. (34) showed a similar observation as B. bifidum and L. fermentum significantly reduced mycelia growth of toxigenic $A$. parasiticus. The inhibition of fungal growth by LAB has been attributed to nutritional competition, secondary metabolites, $\mathrm{pH}$ or their combinations (35). Of the various LAB isolated from "Kati", L. plantarum KLDS 1.0607 displayed the highest hyphal radial growth inhibition against the toxigenic fungus when compared to L. fermentum JCM 8607, L. lactis XLL 1734 and their synergistic combination with a close proximity. A similar result was reported by Wang et al. (36) who observed that CFS of L. plantarum IMAU10014 was able to completely inhibit the growth of plant pathogen named Phytophthora drechsleri. The occurrence and antifungal property of L. plantarum has been reported and thus displayed significance in fermentation and bio-preservation (37).

A number of studies have shown that the inhibition of toxigenic fungi by LAB strains involved the reduction of aflatoxins (AFs) through a binding process to the AFs main sites (38). According to Mishra and Das (39), two significant sites with toxic activities of AFs are furofuran and lactone rings. Altering AFs coumarin structure and cleavage of their difuran rings have been reported to detoxify and change the mutagenic properties of AF molecules $(40,41)$. Hence, antifungal potential of LAB against toxigenic $A$. flavus can be attributed to a wide variety of active antagonistic metabolites like organic acids, carbon dioxide, ethanol, hydrogen peroxide, fatty acids, acetoin, diacetyl, cyclic dipeptides, and bacteriocins (42). The antifungal activity of isolated LAB against toxigenic $A$. flavus could be a result of functional metabolites secreted. Metabolites such as 3-phenyllactic acid, benzeneacetic acid and others produced by L. plantarum were revealed by GC-MS. In the studies of Lavermicocca et al. (43), they have linked 3-phenyllactic acid produced by L. plantarum to its antifungal activity when tested against species of Aspergillus, Penicillium, and Fusarium. Wang et al. (36) attributed the inhibition of $F$. oxysporum, $P$. citrinum and P. drechsleri by L. plantarum to antifungal metabolites like 3-phenyllactic acid and benzeneacetic acid, 2propenyl ester produced by the bacteria, which were detected and identified by using HPLC, LCMS, GCMS and NMR.

There was a reduction in antifungal effect by CFS of LAB when they were synergistically combined against toxigenic $A$. flavus. This observation corresponded to the findings of Marcia et al. (44) who recorded no significant antifungal activity when some commercial starters such as Lactobacillus rhamnosus CIRM-BIA1759, Lactobacillus paracasei CIRM-BIA1761, Lactobacillus plantarum CIRM-BIA 1758 were synergistically tested against yeasts and 
filamentous moulds and thus suggests a low interaction (metabiosis) between the starter cultures and the antifungal adjunct cultures.

\section{CONCLUSION}

Lactic acid fermentation improved the nutritional quality of "Kati" and reduced their anti-nutritional composition; hence, it can be asserted that "Kati" is an acceptable food with different functionality. LAB isolated from "Kati" inhibited the growth of toxigenic A. flavus through the production of lowmolecular-weight antifungal metabolites that created microbial inhibition by competition. The LAB in "Kati" can be used as starter cultures to produce other foods due to their antifungal property, which will improve shelf life of food as well as nutritional values.

\section{Conflict of interest}

None.

\section{References}

1. Omosuli SV, Opawale BO, Ibrahim TA. A survey of bacterial content of 'Egidi' and 'Eko' produced and hawked in Ikare Akoko, Ondo State, Nigeria. Ikere J Sci Teach 2008; 114-7. http://doi.org/10.5251/abjna.2011.1.2.79.81

2. Guyot JP. Cereal-based fermented foods in developing countries: ancient foods for modern research. Intern J Food SciTechnol 2012; 47: 1109-14 http://doi.org/10.1111/j.1365-2621.2012.02969.x

3. Kumari S, Guleria P, Dangi, N. Cereal based beverages and fermented foods: a review. Intern J Enhanced Res Sci Technol Eng 2015; 10: 23197463.

4. Yokotsuka T, Sasaki M. Fermented protein foods in the orient: shoyu and miso in Japan. In J. B. Wood (Edition), Microbiology of fermented foods, Blackie Academic and Professional, London 1998. https://doi.org/10.1007/978-1-4613-0309-1 12.

5. Blandino A, Al-Aseeri ME, Pandiella SS et al. Cereal-based fermented foods and beverages. Food Res Intern 2003; 36: 527-43. https://doi.org/10.1016/S0963-9969(03)00009-7
6. Badmos AHA, Kayode RMO, Amali HE, et al. Fermentation and West African food culture; a review. Global J Bio Sci Biotechnol. 2014; 2:128-32.

7. Kalui CM, Mathara JM, Kutima PM. Probiotic potential of spontaneously fermented cereal based foods - a review. Afri J Biotechnol 2010; 17: 2490-98. http://doi.org/10.4314/ajb.v9i17.

8. Tsafrakidou P, Michaelidou A-M, Biliaderis C. G. Fermented cereal-based products: nutritional aspects, possible impact on gut microbiota and health implications. Foods 2020; 9(6), 734 https://doi.org/10.3390/foods9060734.

9. Olonisakin OO, Jeff-Agboola AY, Ogidi OC, et al. Isolation of antifungal Lactic Acid Bacteria (LAB) from "Kunu" against toxigenic Aspergillus flavus. Preven Nut Food Sci 2017; 2:138-43. http://doi.org/10.3746/pnf.2017.22.2.138.

10. Afolabi EO, Ogidi CO, Akinyele, BJ. First report of nutritional value and consumer acceptability of "Kati" from different cereals using some Lactic Acid Bacteria (LAB) as starter cultures. Carp J Food Sci Technol 2020; 12(3):156-66. 
https://doi.org/10.34302/crpifst/2020.12.3.13

11. Samson RA, Houbraken J, Thrane U, et al. Fungi and indoor fungi. CBS laboratory manual series. Utrecht: CBS-KNAW Fungal Biodiversity Centre, 2010.

12. Cheesbrough M. District laboratory practice for tropical countries, part 2. 2nd ed. Barrow GI, Fellham RKA, eds. Cambridge University Press, Cambridge, UK. 2006; 62-70, 267-330.

13. Cowan, S. T., Steel, K. J. Manual for the identification of medical bacteria. 3rd ed. Cambridge University Press, Cambridge, UK. 1993; 61-3.

14. Thottappilly G, Mignouna HD, Onasanya A, et al. Identification and differentiation of isolates of Colletotrichum gloeosporioides from yam by random amplified polymorphic DNA markers. Afri Crop Sci J 1999; 7:197-207.

https://doi.com/hdl.handle.net/10568/97937

15. Janda JM, Abbott SL. 16S rRNA gene sequencing for bacterial identification in the diagnostic laboratory: pluses, perils, and pitfalls. J Clin Microbiol 2007; 9:2761-4.

http://doi.org/10.1128/JCM.01228-07

16. Association of Official Analytical Chemists (AOAC). Official methods of analysis of A.O.A.C. International 19th Edition. Gaithersburg, MD, USA, Association of Analytical Communities, 2012; 35-60.

17. Okwu GI, Ahar NP, Sharma KS. Quantification of aflatoxin b1 in ready-to-use food thickeners in South-East geo-political zone in Nigeria. Afri J Microbiol Res 2010; 16:1788-93.

18. Criseo L, Bagnara A, Bisignano G. Differentiation of Aflatoxin producing and non-producing strains of Aspergillus flavus group. Letters Appl. Microbiol 2001; 33: 291-5.

http://doi.org/765X.2001.00998.x

19. Salasiah K, Gulam R, Son R. et al. Bacteriocinproducing lactic acid bacteria isolated from traditional fermented food. Malays J Med Sci 2001; 1: 63-8.
20. Lind $\mathrm{H}$, Jonsson $\mathrm{H}$, Schnürer J. Antifungal effect of dairy propionibacteria contribution of organic acids. Int J Food Microbiol 2005; 98: 157-65. https://doi.org/10.1016/j.ijfoodmicro.2004.05.020

21. Adeyemi TOA, Idowu OD, Ogboru RO, et al. Phytochemical screening, nutritional and medicinal benefits of Thaumatococcus daniellii Benn (Benth.). Intern J Appl Res Technol 2014; 8: 92 - 7.

22. Ojekale AB, Makinde SCO. Osileye O. Phytochemistry and anti-microbial evaluation of Thaumatococcus danielli, Benn. (Benth.) leaves. Nig Food J 2007; 2: 176-83. http://doi.org/10.4314/nifoj.v25i2.50858

23. Aref HL, Salah KBH, Chaumont JP, et al. In vitro antimicrobial activity of four Ficus carica latex fractions against resistant human pathogens (antimicrobial activity of Ficus carica latex). Pak J Pharm Sci 2010; 1: 53-8.

24. Shukranul M, Khairana H, Ibrahim J. Ficus carica L. (Moraceae): Phytochemistry, traditional uses and biological activities. Evi Complem Altern Med 2013; 3: 753-76.

http://doi.org/10.1155/2013/974256

25. Osman MA. Effect of traditional fermentation process on the nutrient and antinutrient contents of pearl millet during preparation of 'Lohoh'. J Saudi Soc Agricul Sci 2011; 10: 1-6. http://doi.org/10.1016/j.jssas.2010.06.001

26. Akande KE, Doma UD, Agu HO, et al. Major antinutrients found in plant protein sources: their effect on nutrition. Pak J Nutri 2010; 8: 827-32. http://dx.doi.org/10.3923/pin.2010.827.832

27. Esekheigbe A, Onimawo IA. Effect of Fermentation and heat Treatment on the Nutrient and Antinutrient Composition of African walnut (Tetracarpidiu conophorum). Pak J Nutr 2015; 12: 972-5. http://doi.org/pin.2015.972.975

28. Pranoto Y, Anggrahini S, Efendi Z. Effect of natural and Lactobacillus plantarum fermentation on In vitro protein and starch digestibility of sorghum flours. Food Biosci 2013; 2:46-52. http://dx.doi.org/10.1016/j.fbio.2013.04.001 
29. Modupe EO, Abiodun JO, Adesola, AA. The effect of different starter cultures on the protein content in fermented African locust bean (Parkia biglobosa) Seeds. Int J Eng Res Technol 2016; 4: 2278-0181. http://doi.org/10.1016/j.ijfoodmicro.2005.10.026

30. Muhammad IM, Muhammad IQ, Jafir HS, et al. Beneficial effects of lactic acid bacteria on human beings. Crit Rev Microbiol 2011; 1: 91-8. http://doi.org/10.3109/1040841X.2010.536522

31. Strom K, Sjogren J, Broberg A, et al. Lactobacillus plantarum MiLAB 393 produces the antifungal cyclic dipeptides cyclo (L-Phe-L-Pro) and cyclo (LPhe-trans-4-OH-L-Pro) and 3-phenyllactic acid. Appl Environ Microbiol 2002; 9:4322e7. http://doi.org/10.1128/aem.68.9.4322-4327.2002

32. Gerbaldo GA, Barberis C, Pascual L, et al. Antifungal activity of two Lactobacillus strains with potential probiotic properties. FEMS Microbiol Lett 2012; 1: 27-33. http://doi.org/10.1111/j.1574-6968.2012.02570.x.

33. Russo P, Arena MP, Fiocco D, et al. Lactobacillus plantarum with broad antifungal activity: A promising approach to increase safety and shelflife of cereal-based products. Int J Food Microbiol 2017; 247:48-54.

http://doi.org/10.1016/j.ijfoodmicro.2016.04.027

34. Ghazvini RD, Kouhsari E, Zibafar E, et al. Antifungal activity and aflatoxin degradation of Bifidobacterium bifidum and Lactobacillus fermentum against toxigenic Aspergillus parasiticus. Open Microbiol J 2016; 10: 197-201.

http://doi.org/10.2174/1874285801610010197

35. Magnusson J, Ström K, Roos S, et al. Broad and complex antifungal activity among environmental isolates of lactic acid bacteria. FEMS Microbiol Lett 2003; 1: 129-35.

http://doi.org/10.1016/S0378-1097(02)01207-7

36. Wang H, Yan Y, Wang J, et al. Production and characterization of antifungal compounds produced by Lactobacillus plantarum IMAU10014. PLoS One 2012; 7: e29452. https://doi.org/10.1371/journal.pone.0029452

37. Ruggirelloa M, Nuceraa D, Cannonib $M$, et al. Antifungal activity of yeasts and lactic acid bacteria isolated from cocoa bean fermentations. Food Res Intern 2019; 115: 519-25 https://doi.org/10.1016/j.foodres.2018.10.002

38. Hathout AS, Mohamed SR, El-Nekeety AA, et al. Ability of Lactobacillus casei and Lactobacillus reuteri to protect against oxidative stress in rats fed aflatoxinscontaminated diet. Toxicon 2011; 58: 179-86. http://doi.org/10.1016/j.toxicon.2011.05.015

39. Mishra HN, Das C. A review on biological control and metabolism of aflatoxin. Crit Rev Food Sci Nutr 2003; 43: 245-64. http://dx.doi.org/10.1080/10408690390826518

40. Liu DL, Yao DS, Liang R, et al. Detoxification of aflatoxin $\mathrm{B} 1$ by enzymes isolated from Armillariella tabescens. Food Chem Toxicol 1998; 36: 563-74 http://doi.org/10.1016/s0278-6915(98)00017-9

41. Cao H, Liu D, Mo X, et al. A fungal enzyme with the ability of aflatoxin $\mathrm{B} 1$ conversion: purification and ESI-MS/MS identification. Microbiol Res 2011; 166: 475-83.

http://doi.org/10.1016/j.micres.2010.09.002.

42. Suskovic J, Kos B, Beganović J, et al. Antimicrobial activity; the most important property of probiotic and starter lactic acid bacteria. Food Technol Biotechnol 2010; 48: 296-307.

43. Lavermicocca P, Valerio F, Visconti A. Antifungal activity of 3-phenyllactic acid against molds isolated from bakery products. Appl Environ Microbiol 2003; 69:634-40

http://doi.org/10.1128/AEM.69.1.634-640.2003

44. Marcia LS, Thierry A, Mathilde L, et al. Antifungal activity of lactic acid bacteria combinations in dairy mimicking models and their potential as bioprotective cultures in pilot scale applications. Front Microbiol 2018; 9: 1787. https://doi.org/10.3389/fmicb.2018.01787 


\title{
Procena nutritivnog sastava $i$ antifungalni potencijal bakteriocinogenih bakterija mlečne kiseline iz katija na toksigeni Aspergillus flavus
}

\author{
Paul Oladimeji Gabriel ${ }^{1}$, Clement Olusola Ogidi², Oladipo Oladiti Olaniyi ${ }^{1}$, Bamidele Juliet Akinyele ${ }^{1}$ \\ ${ }^{1}$ Departman za mikrobiologiju, Federalni univerzitet za tehnologiju, PMB 704 Akure, Nigerija \\ ${ }^{2}$ Biotehnološka jedinica, Biološke nauke, Univerzitet Kings, PMB 555, Odeomu, Nigerija
}

\section{S AŽETAK}

U ovoj studiji je prikazan nutritivni sastav katija, fermentisane hrane bazirane na žitaricama, kao i antifugalna aktivnost bakteriocina, koji proizvodi bakterije mlečne kiseline, iz katija na aflatoksigeni Aspergillus flavus (A. flavus). Sadržaj proteina $(9,29 \%)$ u katiju bio je viši $(\mathrm{p}<0,05)$ nego u vlažnom mlevenom fermentisanom sorgumu $(6,17 \%)$. $U$ toku fermentacije mlevenog sorguma do faze spremnog katija, antinutritivni sadržaj bio je smanjen $(\mathrm{p}<0,05)$ od $1,22 \mathrm{na} 0,72 \mathrm{mg} / 100 \mathrm{~g}, 3,13 \mathrm{na} 1,13 \mathrm{mg} / 100 \mathrm{~g}$ i 7,31 na $3,02 \mathrm{mg} / 100 \mathrm{~g}$ za tannin, fenol i fitate, po prikazanom redosledu. Molekularne tehnike pokazale su identitet izolovanih bakterija mlečne kiseline: Lactobacillus pentosus BS MP-10, L. paracasei 4G330, L. brevis ABRIINW, L. casei KG-5, L. sakei soj RFI LAB03, L. fermentum JCM 8607, L. plantarum KLDS 1.0607, L. rhamnosus JCM 8602 i L. lactis XLL1734. Među izolovanim bakterijama mlečne kiseline, L. plantarum, $L$. lactis i L. fermentum imale su značajne zone inhibicije $(\mathrm{p}<0,05)$ od $11,0 \mathrm{~mm}, 9,1 \mathrm{~mm}$ i 7,8 mm, na aflatoksigeni $A$. flavus. Izražen antifungalni potencijal supernatanta $L$. plantarum bez ćelija može se pripisati prisustvu 3-fenilaktične kiseline, fenilsirćetne kiseline, plantaricina (bakteriocina), na šta je ukazala gasna hromatografija - masena spektrometrija (GC-MS). Bakterije mlečne kiseline proizvele su metabolite sa antifungalnim svojstvima, koji su uticali na rok upotrebe, ukus i nutritivni sastva fermentisane hrane.

Ključne reči: žitarica, proksimativan, 3-fenilaktična kiselina, fenilsirćetna kiselina, gasna hromatografija masena spektrometrija, fermentacija 